\title{
Traditional Ethnomedicinal Plants among the Tribes of District Shahdol, Madhya Pradesh, Central India
}

\author{
Nikhil Kanungo \\ Department of Botany, Govt. Autonomous P.G. College Chhindwara, Madhya Pradesh - 480001 (India)
}

\begin{abstract}
Present paper deals with 30ethnomedicinal plants have been identified for the treatment of various disease. Harbarium has been prepared which contains information pertaining to botanical name, local name. plants used, their dose and process of administration. A survey of ethnomedicinal plants of Shahdol district has been carried out with co-operation of Tribal villagers.
\end{abstract}

Keywords: Traditional, Ethnomedicinal Plants, Shahdol Tribes

\section{Introduction}

District Shahdolis situated north eastern part of Madhya Pradesh state. It is lyingbetween $23^{\circ} 17^{\prime} 47^{\prime \prime} \mathrm{N}$ latitude and $81^{0} 21$ '21" E longitude. Total geographical area sums up to 5671 sq. $/ \mathrm{Km}$. and has a population of 908148 . Shahdol is richin vast resources of forest and minerals. It is bounded in the north by Satna and Sidhi district, in the east by Korea district, in the south byAnuppur district, in the west by Umaria district. The area is full of water springs which come out on the top hill slopes. The Shahdol district has average rainfall is $85.11 \%$ and above temperature $13.6{ }^{\circ} \mathrm{C}$. The Kol tribes living in some villages situated in and around Shahdol district. They depend solely on their surrounding forest for most of their requirement for food to ethnomedicinal plants.

\section{Material and Methods}

Shahdol district is floristically very rich and harbours a wide range of biodiversity. People living in these forests and adjacent rural areas depend upon plants for their daily needs and food. Kol tribal villagers have good knowledge about medicinal plants and their uses in different types of diseases A perusal of literature shows that no systematic study and survey from ethnobotanical and ethnomedicinal point of view has been carried out in the present area of investigation.The present communication deals with 30 ethnomedicinal plant used by the tribal communities in habiting the region of Shahdol district forvarious disease treatment by the Tribals. The plants are arranged alphabetically each by botanical name, family, local name and use of plants. Plants were collected during flowering period with the help of tribals and vaidys. Parts of ethnomedicinal plants used in the treatments of many types disease and other informations were recorded as stated by the tribals and vaidyas. The specimens were identified with the help of published floraand relevant authorities. Some other workers who have contributed in the field of ethnobotany as Agrawal (1997), Ahirwar (2010, 2010, 2014), Biswas et al (2003), Busia (2003), Chopra et al (1956), Jain (1963, 1965, 1991, 1981), Khan et al (2008), Kirtikar et al (1999), Kumar (2007), Kala (2005, 2007), Maheswari (1964), Masih et al (2013) and Miller (1990).

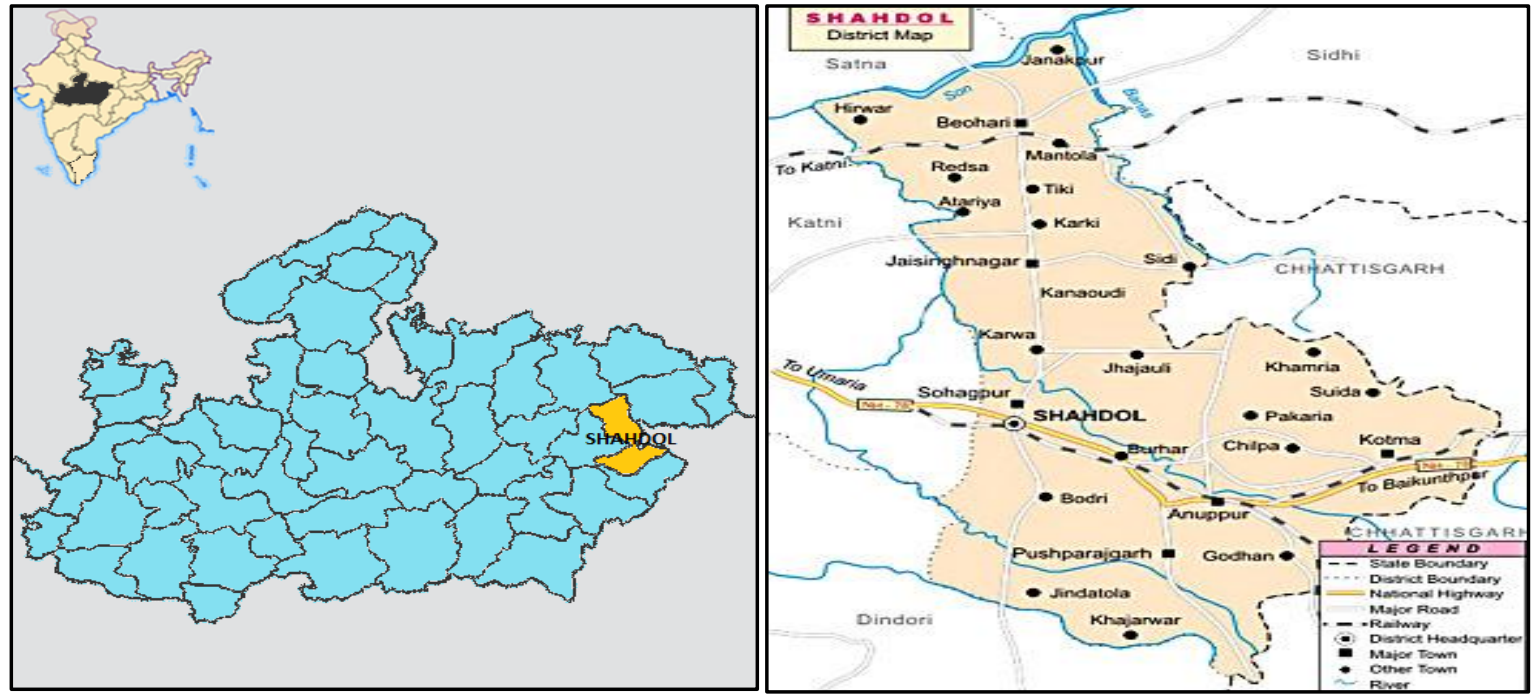

Figure 1: Location Map of Madhya Pradesh in District Shahdol. 


\section{International Journal of Science and Research (IJSR) \\ ISSN (Online): 2319-7064 \\ Index Copernicus Value (2013): 6.14 | Impact Factor (2015): 6.391}

\section{Results and Discussion}

I have identified 30 Ethnomedicinal plants, which are uses by tribals of Shahdol district in their daily life for the treatment of various diseases. Most of these plants are wild and some plants are cultivated. The ethnobotanical plants have been listed alphabetically (Table-1).

Table 1: Shows Traditional Ethnomedicinal plants uses of Tribes in District Shahdol, Madhya Pradesh

\begin{tabular}{|c|c|c|c|c|}
\hline S.No. & Name of Family & Botanical Name & Local Name & Ethnomedicinal Used \\
\hline 1 & Apiaceae & Centellaasiatica(L). Urban & Bramhi & $\begin{array}{l}\text { Entire plant used as nervine tonic, and skin diseases as weak } \\
\text { sedative, cardio depressant, hypotensive and in leprosy. }\end{array}$ \\
\hline 2 & Asteraceae & EcliptaprostrataL. & Kala Bhegraj & $\begin{array}{c}\begin{array}{c}\text { Entire plant tonic given in spleen enlargement and leaf juice given } \\
\text { in eczema and as hair tonic. }\end{array} \\
\end{array}$ \\
\hline 3 & Apocynaceae & Rauvolfia serpentine (L.) Benth. & Sarapgandha & $\begin{array}{c}\text { Leaf juice is used as remedy for opacity of cornea. Root is sedative, } \\
\text { reduces hypertension. }\end{array}$ \\
\hline 4 & Asclepiadaceae & Calotropisprocera Br. & Madar & $\begin{array}{l}\text { Flowers are used in cold, cough and Asthma Powdered Root bark } \\
\text { used in dysentery. Fresh leaves in ulcer and as wormicidal. }\end{array}$ \\
\hline 5 & Acantahceae & Adhatoda VasicaNees & Adusa & Leaf decoction is used in cough bronchitis and rheumatism. \\
\hline 6 & Acantahceae & Hygrophilaauticulata(Schum) & Talmakhana & \begin{tabular}{|c|}
$\begin{array}{c}\text { Leaves, seeds and roots are used as diuretics and also for jaundice, } \\
\text { dropsy, rheumatism and urinogenital disorder. }\end{array}$ \\
\end{tabular} \\
\hline 7 & Amaranthaceae & AchyranthesasperaL. & Chirchitta & $\begin{array}{c}\text { Used in cough and its decoction is given in renal dropsy and } \\
\text { bronchial infection treatment of phyrrhoea fever,enlargement of } \\
\text { liver and spleen. }\end{array}$ \\
\hline 8 & Bombacaceae & Bombaxceiba L & Semur & Root is stimulant, tonic and chiefly given in impotency. \\
\hline 9 & Combretaceae & $\begin{array}{l}\text { Terminalia arjuna(Roxb.) Wt. } \\
\qquad \mathrm{Am} .\end{array}$ & Arjun & $\begin{array}{l}\text { Bark infusion used in heart troubles and leaf juice in earache, } \\
\text { hypertension and as diuretic and has tonic effect in cirrhosis of } \\
\text { lever. }\end{array}$ \\
\hline 10 & Cucurbitaceae & Cocciniagrandis $(\mathrm{L})$. Voigt & Kundru & Juice from leaves and roots is used in diabetes. \\
\hline 11 & Cactaceae & Opundtiaelatior. Mil. & Nagphani & $\begin{array}{l}\text { Baked fruit is given in whooping cough and a syrup of the fruit } \\
\text { increases secretion of bile. }\end{array}$ \\
\hline 12 & Caesalpiniaceae & Cassia fistula $\mathrm{L}$. & Amaltash & $\begin{array}{l}\text { Root with black pepper and leaves of kathal applied to cattle for } \\
\text { giving relief to swollen throat. }\end{array}$ \\
\hline 13 & Caesalpiniaceae & Cassia tora $\mathrm{L}$. & Chakwda & Leaf and seeds used in skin disease for ring worm and itch. \\
\hline 14 & Convolvulaceae & CuscutareflexaRoxb. & Amarbel & Seeds used in ulcer and liver disorders. \\
\hline 15 & Dipterocarpaceae & Shorearobusta $\quad$ Gaertn f. & Sal & Resin is used in skin diseases, diarrhea anddysentery. \\
\hline 16 & Fabaceae & $\begin{array}{l}\text { Butea monosperma(Lamk) } \\
\text { Tamb }\end{array}$ & Palas & $\begin{array}{l}\text { Seeds are internally administerd as an anthelmintic in treatment of } \\
\text { round worms. Gum is used in treatment of diarrhoea. }\end{array}$ \\
\hline 17 & Fabaceae & DalbergiasissooRoxb & Shisham & Decoction of leaf Useful in gonorrhoea. \\
\hline 18 & Fabaceae & Mucunapruriens(L) DC & Kemmach & $\begin{array}{l}\text { Root used in paralysis seeds are used as nervine tonic, menses } \\
\text { troubles and as vermifuge, strong infusion of roots mixed with } \\
\text { honey is given in cholera. }\end{array}$ \\
\hline 19 & Lythraceae & LawsoniainerdmisL. & Mehndi & $\begin{array}{l}\text { Lea paste or decoction used as gargle in sore throat, burns, bruises } \\
\text { and skin inflammation, Seeds useful in urinary troubles. }\end{array}$ \\
\hline 20 & Lamiaceae & $\begin{array}{l}\text { Leucascephalotes(Wild.) (Roth) } \\
\text { Spr. }\end{array}$ & Gumi & $\begin{array}{l}\text { Leaf used as digestive antiseptic and earache and fever. Flowers are } \\
\text { used in cough and cold. }\end{array}$ \\
\hline 21 & Lamiaceae & Ocimumamericanum $\mathrm{L}$. & Kali tulsi & Leaf decoction is given in Maleria and abdominal diseases. \\
\hline 22 & Menispermaceae & Tinosporacordifolia $(\mathrm{L}$.$) Merr$ & Gurch & $\begin{array}{l}\text { Root extract is used in fever, cold cough, as blood purifier, in } \\
\text { acidity and jaundice. }\end{array}$ \\
\hline 23 & Meliaceae & Azadirachtaindica A. Juss & Neem & $\begin{array}{l}\text { Bark, leaf and fruit decoction is antiseptic and used in ulcer, eczema } \\
\text { and skin diseases. }\end{array}$ \\
\hline 24 & Iimosaceae & Acacia nilotica (L.) Del. & Babul & Bark used in diarrhea, dysentery and diabetes. \\
\hline 25 & Mimosaceae & Albizdialebbeck (L.)Willd & Siris & Bark and seeds given in piles and diarrhea. \\
\hline 26 & Nyctaginaceae & Boerhaaviadiffusa $\mathrm{L}$. & Punarnava & Root is laxative and used in asthma, jaundice and dropsy. \\
\hline 27 & Papaveraceae & Argemonemexicana $\mathrm{L}$ & Pilikateli & Stem latex used in dropsy, jaundice and conjunctivitis. \\
\hline 28 & Papaveraceae & Papaver somniferum $\mathrm{L}$ & Afeem & $\begin{array}{l}\text { Flower, fruits and Seeds have pain releasing and sleeping effects } \\
\text { and useful in irritating cough, pneumonia, ulcers, gastritis and } \\
\text { influenza }\end{array}$ \\
\hline 29 & Rutaceae & Aegle marmelos (L)Corr & Bel & $\begin{array}{c}\text { Fruits is given in diarrhea dysentery irriation of alimentary canal, } \\
\text { fever and as tonic and cooling agent. }\end{array}$ \\
\hline 30 & Sapotaceae & $\begin{array}{l}\text { Madhucalongifolia(Koen) Mac } \\
\text { Br. }\end{array}$ & Mahua & $\begin{array}{c}\text { Decoction of bark is used in incurring bleeding gums and ulcers. } \\
\text { Flowers are used in cough and bronchitis. }\end{array}$ \\
\hline
\end{tabular}

\section{Acknowledgement}

The author is highly thankful to the Principal, Govt. Autonomous P.G. College, Chhindwara for moral support and for granting permission to carry out this work. The author is also very much thankful to the tribal and rural people for sharing their knowledge on various ethno medicinal plants and their uses.

\section{Volume 5 Issue 6, June 2016 www.ijsr.net}

Licensed Under Creative Commons Attribution CC BY 


\section{International Journal of Science and Research (IJSR) \\ ISSN (Online): 2319-7064}

Index Copernicus Value (2013): 6.14 | Impact Factor (2015): 6.391

\section{References}

[1] Agrawal, D.P. (1997) Traditional Knowledge Systems and Western Science current science73, 731-733.

[2] Ahirwar,R.K. (2010) A Survey of Medicinal Plants used by tribals of Anuppur District, central India.Ind. J. Applied \&Pure Bio. Vol.25 (II) 227-230.

[3] Ahirwar,R.K. (2011) Ethnomedicinal Plants Studies in Jaitpur Forest range of Shahdol, District, Central India. Ad. PlantSci. Vol.24 (II) 681-684.

[4] Ahirwar,R.K. (2014) Utilization of Medicinal Plants by the Tribes of Bhatiya, District Shahdol, Madhya Pradesh. Int.J.Sci.andRes.3(9).149-151.

[5] Ahirwar, R.K. (2010) Ethnomedicinal uses of plant roots from Shadol district of M.P. India. Ind. J.Appl. Pure Bio. 25 (1) 71-76.

[6] Ahirwar, R,K. and Singh,G.K. (2011) Some anti diabetic plants from Dindori District of Madhya Pradesh (India). Ind. J.Appl. pure Bio.26 (2) 269-271.

[7] Biswas, T.K. and Mukherjee, B. (2003) Plant Medicines of Indian Origin for Wound Healing Activity: A Review. In- ternational Journal of Lower Extremity Wounds, 2, 25-39.

[8] Busia, K. (2005) Medical Provision in Africa-Past and Present. Phytotherapy Research, 19, 919-923. http://dx.doi.org/10.1002/ptr.1775

[9] Chopra R.N, Nyar SL \& Chopra I.C.(1956) Glossary of Indian Medicinal Plants, Council of scientific and Industrial Research, New Delhi.

[10] Hemadri, Koppala\&Rao.S.S.(1989) Folk Medicine of Bastar,J.Ethnobotany1, 61-66.

[11] Jain S.K. (1963) Observation on the Tribals of Madhya Pradesh Vanyajati.11, 177-183.

[12] Jain, S.K. (1991) Dictionary of folk Medicines and Ethnobotany, Deep Publications, New delhi.

[13] Jain, S.K . (1981) Glimpses of Ethnobotany, Oxford \& IBH. NewDelhi.

[14] Jain, S.K.(1965) Medicinal Plant lore of tribals of Bastar Econ.Bot, 19, 236-250.

[15] Jain, S.P. Singh, S.C. (1994) Ethno-medico-botanical survey of Ambikapur, Madhya Pradesh, IV ICE, Lucknow, Nov.17-21.

[16] Khan.A.A, Agnihotri, S.K, Singh M.K \& Ahirwar, R.K. (2008) Enumaration of certain Angiospermic plants used by Baiga tribefor Conservations of Plants Species. Plant Archives8, (I) 289-291.

[17] Kirtikar, K.R. \&Basu,B.D.(1999) Indian Medicinal Plants ( International book Distributors Book sellers and Publishers, Deheradun.) Vol. 3.

[18] Kumar, K. (2007) Working Plan of North Surguja, Ambikapur Forest Department Govt.of Chhattisgarh, Raipur.

[19] Khan.A.A, Agnihotri, S.K, Singh M.K \& Ahirwar, R.K. (2008) Observation of Certain Plants used in skin diseases by Baiga Tribes of Mandala district. Plant Archives 8. (I) 283-284.

[20] Kala, C.P. (2007) Local Preferences of EthnoBotanical Species in the Indian Himalaya: Implications for Environmental Conservation. Current Science, 93, 1828-1834.

[21] Kala, C.P. (2005) Indigenous Uses, Population Density and Conservation of Threatened Medicinal Plants in Protected Areas of the Indian Himalayas. Conservation
Biology, 19, 368-378. http://dx.doi.org/10.1111/j.15231739.2005.00602.x

[22] Maheswari, J.K. (1964) A Contribution to the FloraKanha National Park, Madhya Pradesh Bull. Bot. surv.India. 5(2), 177-140.

[23] Masih, V., Sahu, P.K. and Singh, M. (2013) Observation on Ethno-Medicinal Herbs of Dantewada, Chhattisgarh India. Interna- tional Journal of Drug Discovery and Herbal Research,3, 644-648.

[24] Miller, N.N., (1990) Traditional medicine in East Africa, America universities field staff report, 22, pp 115.

Volume 5 Issue 6, June 2016 www.ijsr.net 